\title{
The Approach of Knowledge Transfer in Deriving Shafi'ite Hukum
}

\author{
Wan Zulkifli Wan Hassan
}

National University of Malaysia

Email:wenzoul@ukm.edu.my

Jamsari Alias

National University of Malaysia

Email: jamsari@ukm.edu.my

\section{Ezad Azraai Jamsari}

National University of Malaysia, Department of Arabic Studies and Islamic Civilization,

Faculty of Islamic Studies, Universiti Kebangsaan Malaysia, 43600 UKM Bangi, Selangor, Malaysia

Email: eajsti@gmail.com

Luqman Abdullah

University of Malaya

Email: luqmanabdullah@um.edu.my

Sidek Abdullah

Mara University of Tecnology Johor Email: sidek973@johor.uitm.edu.my

\section{Doi:10.5901/mjss.2015.v6n1s1p260}

Abstract

The management and transfer of knowledge have been actively discussed lately, specifically in relation to managing information. However, it is not yet actively pursued from other angles, for example, relating to religion, especially Islam. This paper takes the perspective of the making of the rules, specifically by the Shafiites, by seeing how knowledge transfer can be carried out in the process of hukum making. The knowledge transfer approach through the 'replication' and 'adaptation' methods will be emphasised and fully explained. This paper will also show that the process of establishing a rule in the Shafii madhhab applied knowledge transfer via replication and adaptation. Using these two approach, the Shafi'ites seem to have successfully expanded their teachings globally. In fact, these applications were able to solve many problems of the Islamic community today.

Keywords: Knowledge transfer; the deriving of hukum; Shafiite; madhhab.

\section{Introduction}

With the rapid development of the world today, many are not aware of the process of learning and education, let alone understand how the transfer of knowledge can occur. Studies by academicians and scholars found that to teach and transfer knowledge, understanding the culture and the behavioural patterns of the target group is important (Hollins, King \& Hayman, 1994; Pai, 1990; Smith, 1998). Two approaches to the transfer of knowledge which also require local adaptation (or localisation) have been identified. The two approaches are known as 'replication' and 'adaptation' (Szulanski, 2000). Replication means that a particular discipline of knowledge and practice on that knowledge are replicated in their entirety and as closely as possible, while adaptation allows modification and changes to be done on that transferred knowledge, so that the context and understanding remain (Szulanski, Winter, Cappetta \& Vanden, 2002; William, 2007). Hence, when studying how the Shafi'ite laws were derived, the process of analysing it from the perspective of knowledge transfer should be given due attention. Thus, the approach of knowledge transfer and its 
management, which is rather new, will in this paper be matched with the process of law making in the Shafilite madhhab (school of jurisprudence/thoughts), so that a new fresher perspective can be obtained in the field of social sciences, generally, and knowledge management, specifically.

In the history of Islam, knowledge relating to jurisprudence spread through the spread of Islam itself which was spread or transferred by the ulema (Islamic scholars). To dignify the teachings and rules of Islam, only those with the expertise in Islamic jurisprudence were authorised to determine any particular ruling when there arose new issues requiring explanation to the society. In the process of transferring knowledge such as Islamic jurisprudence, a number of ulema preferred to use the method of taqlid (imitation)) and talfiq (combination) in producing fatwas (edicts), as they were less capable of having consultations using their own methodology on rulings. Instead, they consulted within the framework made available by other earlier madhhabs (Sheikh Abdul Halim, 2008). Taqlid means to practise or apply an opinion without basing it on evidence while sto follow the decisions of a mujtahid (scholar of Islamic law with comprehensive understanding of the texts and reality) without necessarily examining the scriptural basis or reasoning of that decision, such as accepting and following the verdict of scholars of figh (jurisprudence)\}. Talfiq means to compile and merge both opinions and doctrines in a particular problem in order to produce a particular ruling and concept as a result of the combination when other schools of thought are not of the same opinion and do not recognize such methods (alGhazali, 1356; al-Qal'aji \& al-Qunaybi, 1985).

In determining a particular ruling therefore, ulema need to have expertise in extracting the laws found in a nas (scriptural verse) as well as use the approach of knowledge transfer which had been outlined by previous scholars or the mechanism of ijtihad (personal reasoning) which they had introduced. By this way, every edict decided will ensure the existence of harmony and benefit to the people without sidelining any ruling that had been clearly expressed in the alQur'an (Koran) and in the al-Sunnah. Hence, Shafiite ulema used the knowledge transfer approach appropriately to ensure that every edict thereafter can be decided justly and meet the objectives of Shari'ah as well as meet the needs of current times and localities (al-Qaradawi, 1990).

\section{Research Methodology}

In carrying out any study, data collection and analyses are important together with careful preparation and planning in order to achieve the purpose of obtaining and expanding knowledge. Hence, in this study the writer has taken a qualitative method via an in-depth literature review by applying two methods as follows:

\subsection{Data Collection}

The method of data collection was used to obtain and compile the information and facts for the purpose of the study. In the context of this study, data was obtained from both primary and secondary sources being documents, books and manuscripts to ensure that the facts put forward are accurate. In addition, electronically published materials were used to obtain the latest information and data from articles and other materials, on fatwas and other matters related to it.

\subsection{Data Analysis}

The method of data analysis was used to study, summarise and analyse the data compiled. In particular, the writers/authors used a qualitative analysis method specialising in historical questions resulting in an opinion on the transfer of knowledge in the making of Shafi'ite hukum (verdicts/ruling). To elaborate, the writer used two analytical approaches being:

- An inductive analysis, i.e. a process of logic that provides a general explanation based on specific observation.

- A comparative analysis, i.e. a technique of analysis used to compare an issue or an opinion with another issue or opinion.

\section{The Knowledge Transfer Scenario in the Deriving of Hukum by Shafi'ites}

The knowledge transfer approach in the making of the Shafi'ite rulings was a process carried out by al-Shafili himself, or by ulema who followed the teaching of the madhab ('ulama' al-Shafi'iyyah) guided by books written by al-Shafi'i himself or the 'ulama' al-Shafi'iyyah, to the extent that a Shafi'ite school of figh was successfully established (Ali \& Ismail, 2007). The Shafi'ite school of jurisprudence is comprised of views of the majority of mujtahidin ulema within the Shafi'ite teachings who are still tied to the methodology of hukum-deriving which had been introduced by al-Shafi'i, even though 
only a few breached it. According to al-Shafi'i, there are five sources of laws: firstly, the Koran and al-Sunnah (al-Nusus), secondly al-ljma' (consensus), thirdly aqwal al-sahabah (the views of the Companions), fourthly the differences of opinion among the Companions and fifthly, al-Qiyas (analogical reasoning). The arrangement is based on Islamic authorities on jurisprudence (al-Shafi'i, 1993).

In the Shafi'i madhhab, every opinion can be considered as that of the Shafi'ite stream as long as it stays within the policy which had been determined and does not go against al-Shafili's opinions (Amin, 1964; al-Haqq, 1991). The process of developing the Shafi'ite school of thoughts is through knowledge transfer such as tarjih (a specific verdict or preference) and takhrij (extraction) activities amongst his students and scholars, the mujtahidin ulema and the efforts to spread or transfer knowledge increased within the madhhab. As a mujtahid, the Imam had his own views when putting forward the methodologies and policies underlying rule formation.

Even at the initial stage, al-Shafili was one of the ulema who had studied the methodology put forward by the ahl al-Ra'y stream, pioneered by Imam Abu Hanifah as well as being one of the strong defender of the views and verdicts proposed by Imam Malik. However, after he studied the ahl al-Ra'y views, he tried to bring forth an adaptation and a reformation by proposing a new method of issuing verdicts whereby a compromise is reached in order to combine the two streams of ahl al-Hadith and ahl al-Ra'y (Abu Zahrah, 1987; al-Syak'ah, 1997, Abu Talib, 1990). In fact, he had expressed his feelings to himself while he was in Iraq, following the chaos in the Iraqi Muslim community then, with raging debates and heated discourse between the panel of fuqaha' ahl al-Hadith and ahl al-Ra'y, "...l feel that it is time for me to liberate them (the Iraqi community) from the ahl al-Hadith and ahl al-Ra'y streams..." (al-Syak'ah, 1997; Abu Zahrah, 1948).

Hence, when he returned to Mecca from his academic journey to Baghdad, Iraq, one which lasted almost nine years, he made the decision to develop and transfer his own thoughts and his own methodology of deriving hukum. While he was in Baghdad for two years only, a period that can be said to be brief, he became a disciple of Imam Malik who differed from his teacher from the aspect of methodology and opinions (Abu Zahrah, 1948). After two years in Baghdad, al-Shafi'i wanted to return to Mecca. While he was in Mecca he continued to serve as an 'alim by holding academic gatherings which were attended by both the residents of Mecca and the Muslim community who were present to perform their pilgrimage. It was here that he seriously expounded on his own views and approach, which were not strictly tied to the figh methodology of the Hanafites and the Malikites (Abu Zahrah, 1948).

The reformation of figh and rules methodology introduced by al-Shafi'i was widely covered in Baghdad. A renowned Iraqi 'alim at that time, 'Abd al-Rahman Mahdi, sent a letter to him requesting to arrange the documents in a book with explanations on the Koran, compilation of hadiths, the theories of al-ljma', and clarification of the relationship between nasikh (the abrogating) and mansukh (the abrogated) contained in the al-Qur'an and hadiths. Consequently, alShafi'i then made the decision to compile al-Risalah, as a guide to the mujtahid and was the result of his work in Mecca (Abu Zahrah, 1948; al-Baghdadi, 1997).

At the same time, al-Shafi'i began to write several books. In the field of figh he wrote Kitab al-Hujjah, one of the first books he authored, and is a collection of his rulings (al-Shafi'i, 1993; al-Nawawi 1997). Al-Risalah which discussed the relationship between usul al-figh (principles of jurisprudence) was written and completed while he was in Egypt. With these two works, al-Shafili expanded his thoughts and methodologies, later named madhhab qadim or qawl qadim. Ahmad Ibn Hanbal, al-Za'farani and al-Karabisi were amongst his disciples tasked to spread the madhhab and its fatwas while in Baghdad (al-Zuhayli, 1988). In developing and transferring the Shafi ite based legal knowledge, the disciples played an important and active role in spreading the madhhab and the transfer of Islamic jurisprudence knowledge. They were located in the major cities of the Islamic countries such as Iraq, Mecca, Egypt, Syam (Syria) and Yemen. Most of his students turned to al-Rabi' Ibn Sulayman in Egypt after his death, and thereafter they went to other places such as Naysabur, Khurasan and others. Although they were far apart from each other, they were united under the same school of thoughts (Abu Zahrah, 1987).

Hence, it is appropriate to put forward the methodology and several approaches undertaken by al-Shafiit in formulating Islamic hukum from various sources. The basis of his thoughts and thinking about Islamic verdicts can be seen in his two great works, the al-Risalah and the al-Umm (Abu Talib, 1990; al-Razi, Undated). The Approach of Knowledge Transfer through the methods of replication and adaptation was seen existent in the comprehensive deriving of Shafi'ite rulings. The following explanation will show that the process of arriving at a hukum in the Shafi'ite madhhab used the approach of knowledge transfer both by way of replication and adaptation. By these two methods, the Shafi ites are seen to have been successful in spreading and strengthening the Shafili madhhab to all corners of the world. 


\section{The Replication Approach in the Deriving of Rules}

As the founder of Shafi'ite school of figh, al-Shafi'i himself used the approach of replication in using the Koran and alSunnah as important sources and medium as well as being the absolute foundation of the development of the madhhab. He held the view that the interpretation of Koran is of equal weight as al-Sunnah from the aspect of producing a particular hukum. He thought that both were major sources in Islamic jurisprudence and could not be disputed. All other sources available would be resulting from or based on these two major sources. Notwithstanding that, his views were clearly different from the views that have been put forward by other ulema in relation to the categorization of sources of rules. Imam Abu Hanifah and the other ulema after him placed al-Sunnah as the secondary source after Koran (Abu Zahrah, 1987). Abu Zahrah (1987) had suggested three reasons on why al-Shafi'i placed Koran and al-Sunnah as a medium of equal value in producing rules, as follows:

- Al-Shafii set out that knowledge on al-Sunnah had the same position as the Koran in making to conclusions on ancillary rules, and he never once denied that the Koran is the basis and core of the religion, the debates and the miracles of the Prophet p.b.u.h. Al-Sunnah assists the Koran in explaining the rules in the Koran in line with daily life and customs.

- Al-Shafiti made the knowledge of al-Sunnah as a whole equal to the Koran in explaining the ancillary rules to ensure that the istinbat (deduction, inference) can be done in the right way. However, he did not assume that all the hadiths narrated by the Prophet p.b.u.h. had similar position with the Koran which is mutawatir. Mutawatir Hadith is the hadith that was narrated by the Prophet p.b.u.h. of such a large number of narrators from one generation to the other generation. Normally, it would be impossible for falsification of the hadith as there were a large number narrating it, and the narrators were trustworthy, even though they may have been under different circumstances, time or place (Khallaf, Undated). Hence, hadiths bearing the nature of ahad did not bear the same weight as those hadiths that are mutawatir especially compared to the Koran. Al-Ahad Hadith is the hadith that was conveyed from the Prophet p.u.b.h. by a number (singular) of narrators. The number was not as large as that of al-Mutawatir at every stage, i.e. the generation of the Companions, tabi'in (the generation of Muslims who were born after the death of the Prophet Muhammad p.b.u.h. but who were contemporaries of the Companions) and tabi' al-tabiin (the Muslim generation after the tabiin in Islam). The narrations of these hadith would have zann (a very strong presumption) on its authenticity. As such, the majority of the ulemas declared that it is compulsory to believe in them and can be used as an argument (Khallaf, Undated; Hasyim, 1995). Al-Shafiit had once stated, in relation to this discussion that, "the most elevated position is the al-Kitab and al-Sunnah when it is thabit (strong/permanent)".

- Al-Shafi'i also explained that al-Sunnah did not have the same position (weight) as the Koran in matters relating to faith. This can be seen from the dalil (proofs, evidence, justification) submitted by al-Shafii in several matters relating to prophet hood and divinity. Al-Shafi'i mainly used the proofs from the Koran compared to al-Sunnah (al-Razi, Undated).

In connection with the Koran, al-Shafili had declared that the text in the Koran were conveyed by way of mutawatir and explicit, thus making it the most important source in determining a rule without need for dispute (al-Shafi'i, 1309). In fact the contents of the Koran provide explanation and guidance for all types of issues faced by mankind, especially for the Muslims. In the context of knowledge transfer, he used the replication method by making the Koran as a medium in structuring and constructing a rule directly and absolutely. Al-Shafi'i asserted that the Koran had provided two methods in justifying rules. Firstly, the nas (texts) of the Koran which do not require further explanation from al-Sunnah in clarifying its intent, and secondly, the nas from the Koran which required further explanation from the al-Sunnah.

In defending the position of hadith as a source for rules, al-Shafiti was seen as nasir al-Sunnah (upholder of alSunnah). He had formulated several systematic methods in the acceptance of hadith which must be upheld and followed absolutely and complementary to the Koran, hence disputing the claims of anti-hadith groups who were present in his time (Abu Zahrah, 1987). According to al-Shafi'i, hadith sahih (authentic/sound) must be accepted totally and absolutely as they do not contradict the Koran. This was summarized from his sayings, "when a hadith is sahih (authentic/sound) then that is indeed my teaching and disregards my words" (al-'Asqalani, 1301). Hadith sahih is the hadith told by the narrators who had the characteristics of being just and with strong and sharp memory. In addition, their sanad (the chain of narrators of hadith) were continuous and did not contain any flaw or shadh (oddity) from the beginning of the sanad to the end (Hasyim, 1995).

In relation to the above view, al-Nawawi (1997) summarised that the quote from al-Shafi'i meant that one should not continuously accept a hadith sahih and practice it on the surface without carrying out further research and analysis on the hadith. As such, it can be concluded that al-Shafi'i viewed hadith sahih as hadiths which meets the meaning and 
intent of the Koran. The methods introduced by him in accepting the hadith sahih are seen to be appropriate with the replication approach in the transfer of knowledge.

In the book of al-Risalah, al-Shafi'i proposed several methods of resolution (tawfiq) between conflicting hadiths, so that the source from the hadith can be accepted totally. One of which is to know which hadith was mansukh (the abrogated) and which was nasikh (the abrogating). Thus, the hadith nasikh must be accepted as it cancels the mansukh. However, al-Shafi'i outlined three methods of resolution if it is not known which hadith is nasikh or mansukh. Firstly by studying which of the two were first related and which came after. The hadith that was related first would be considered as the mansukh in addition to researching the background of the hadith as to why it was related. Secondly, the strength of its sanad (the chain of narrators of hadith) would be taken into account if it is not clear which of the hadith came first and which came after. Thirdly, to accept any hadith that is supported by verses from the Koran, and other hadiths. Al-Shafi'i stated that the role of al-Sunnah or hadith in respect of the Koran is:

- Al-Hadith supports and provides further clarification on the intention of the Koran. This is when the contents of the hadith bear the same meaning as the Koran.

- Al-Hadith narrows down the verses of the Koran which are general in nature.

- Al-Hadith interprets and clarifies any ambiguity of the Koranic verses and limits the absolute verses.

- Al-Hadith explains rules that are not referred to specifically from the Koran.

- Al-Hadith also acts as a source to identify the verses which are nasikh and mansukh in the Koran. Nasikh and mansukh must be based on proof and arguments. Hence, hadiths provide the proof and justifications on its relevance.

With this, it can be summarised that al-Shafi'i placed the Koran and al-Sunnah as primary sources of rule construction and are important in finding proof and justification of any particular rule. This is because the entire contents of the Koran came from Allah the Almighty and all are therefore true without any doubt or falsification. Whereas the role of al-Sunnah is substantial as it was brought about and conveyed through the Prophet p.b.u.h. In fact, he himself played a role in the interpretation of the Koran and, hence, it was more complete. Aside from the Koran and al-Sunnah, al-Shafii also applied the replication approach in transferring of knowledge through the process of al-ijma' as one of the sources in constructing the rulings in his schools of figh. According to him, al-ijma' is a consensus of the mujtahidin ulema in respect of a rule at any particular time. In addition, he said, al-ijma' would not happen if not agreed to by the ulema with respect to fundamental religious policies such as the obligations of prayers, fasting, paying zakat, pilgrimage and others. This is based on a quotation from him: "other scholars and I will not say that a particular matter is al-ijma' unless there is someone from the ulema who holds the same view and tells us that this was the view of the previous scholars".

The application of al-ijma' by al-Shafili as a basis for making hukum is based on a hadith related by Sulayman b. Yasar which told of how 'Umar ibn al-Khattab once spoke before the Muslims in Jabiyah saying:

"Indeed the Prophet p.u.b.h. stood before us as I stand before you today, and he said, "Honour my Companions, and the generation after them (tabiiin) and the generation that comes after that (tabi' tabiin), and thereafter there shall appear falsehood among mankind, to the extent that they will be willing to swear without being asked to do so, and willing to be a witness without being asked to do so. Know, that whomsoever desiring heaven, must bind himself to a group (congregation) as Satan loves the company of one and not the company of two (or more)."

Al-Shafii said the above hadith clearly showed the importance of being in a group, and even though not physically or externally, at least the group is united in determining the halal (permissible) and haram (prohibited/unlawful) of any particular matter. According to al-Shafi'i, al-ijma' that should be given preference is al-ijma' between the Companions of the Prophet p.b.u.h. It does not however mean that he rejected al-ijma' as a source for law if they are submitted by others than the Companions. Hence, the following three were given attention by al-Shafii (Abu Zahrah, 1987):

- Al-Shafi'i considered that al-ijma' should come next after the Koran and al-Sunnah in the search for proof. Hence al-ijma' cannot be used if it conflicts with the Koran and al-Sunnah. Additionally, in reality, al-ijma would not be possible if it goes against the two sources and the implementation of it is not supported by historical facts.

- Al-Shafi'i did not consider al-ijma' carried out by the people of Medina as al-ijma' in its true sense. His view is against that held by his teacher, Imam Malik. However when seen from the practical aspect, the people of Medina did not perform al-ijma' unless it is compatible with what had been ijma' by the Muslim communities in other Islamic lands. Therefore from the practical aspect, al-Shafi'i did hold the same view with his teacher, even though theoretically there are differences.

- According to al-Shafi'i, a claim that an al-ijma' had occurred must be investigated properly and thoroughly. The 
claim must be rejected if there is a possibility that it could be rejected.

Based on the above, it can be summarised that al-Shafi'i accepted al-ijma' absolutely and applied the replication approach in the rule constructions, by using the method of al-ijma' once all the conditions are fulfilled for it to be used as a source of law and debate in forming justification (proof). He placed al-ijma'as second to the Koran and al-Sunnah, as a source of law, even though it was conveyed through Al-Ahad hadith. In qawl al-qadim (the former doctrine) of al-Shafi'i, he had emphasised that the views of the Companions (aqwal al-sahabah) were a source in the making of the law, exceeding al-qiyas (Ibn al-Qayyim, Undated). However, in his qawl al-jadid (new doctrine), he amended his own views by declaring that the views of the Companions were only a source if accompanied by al-qiyas, which will hold priority over other views of Companions (al-Bannani, Undated). There were those among the usul al-figh ulema such as al-Ghazali, alAmidi and others after al-Shafi'i, who claimed the existence of an opinion in the al-Shafi'i madhhab, acknowledged by the Shafi ite ulema, which stated that the Companions' views are not considered as a source of law (al-Ghazali, 1356; al'Amidi, 1347).

However, from the study of the al-Risalah book, written by al-Shafi'i and narrated by al-Rabi' b. Sulayman, it is clear that he applied the replication approach in continuing to accept aqwal al-sahabah (the views of the Companions) as a source of hukum if supported by texts from either the Koran or al-Sunnah or al-ijma' or al-qiyas. In addition, he also once stated that aqwal al-sahabah (the views of the Companions) were one of the sources of law that he categorized into five stages as previously stated. In connection to this, al-Shafili had divided the views of the Companions to three categories (Abu Zahrah, 1987):

- Opinions that were obtained through ijma' amongst the Companions such as their consensus on that an Islamic government can charge kharaj (land tax) from the agricultural produce of land taken by the Muslim soldiers in war, but surrendered to the original owners to be cultivated, without dividing it with the Muslim army (Abu Yusuf, 1352). Such opinions are seen as a source of law as there was ijma' on them and the views were not at all disputed.

- The view of a Companion which was neither objected to expressively nor clearly accepted by any of the Companions. These views were acceptable by al-Shafi'i.

- Views of a companion which contradict that of other Companions. In this matter, Imam Abu Hanifah and Imam al-Shafi'i on the whole accepted the opinion of the Companions as a source of law. However, they would choose the opinion of the companion closest to the Koran or Al-Sunnah or al-ijma' or reinforced by al-qiyas.

At the same time, al-Shafi'i would use or apply the opinions of Khulafa' al-Rashidin (Abu Bakr, 'Umar, 'Uthman and 'Ali) if there were similarities with the opinions of the Companions. This is because, in determining any particular rule or view, in general, the Khulafa' al-Rashidin would have asked the other Companions on rules in the Koran and al-Sunnah if they could not find any texts regarding the particular rule. They then would hold a discussion before determining the rule or verdict if the issue could not be resolved by those texts. The rules and verdicts would be published and not retracted if there were no objections from the other Companions (Abu Zahrah, 1987; Bik, 1965).

From the above clarification, it is clear that al-Shafi'i placed the Koran, al-Sunnah, ljma' and views of the Companions as the fundamental basis in the deriving of hukum within his madhhab, and this is seen as the approach of knowledge transfer by way of replication, that is, a knowledge or practice on that knowledge, is replicated in total or as closely as possible. In fact, the deriving of Islamic ruling that does not meet the criteria as found in the abovementioned sources would be deemed as void and rejected.

A number of ulema within the Shafi ite denomination used the replication method in transferring knowledge and spreading it. This is seen from the existence among them of mujtahid ulema who did not meet the full criteria of a true mujtahid due to them not having the expertise in determining any particular rule by themselves. In other words, they were not able to master the area of usul al-figh or other fields of knowledge which would have enabled them to perform ijtihad, even though they may be a fagih (an expert in Islamic jurisprudence) in their Imam's teachings and would have known and been able to explain, consider and analyse the proof of their Imam's teachings (al-Nawawi, 1997; Bik, 1965).

This is similar to the mujtahid ulema who were able to resolve issues by memorising the views and verdicts of their Imam's teachings and to quote and understand each issue brought up in their Imam's book of rules in total or to apply the replication approach, be it simple or complicated. However, they would not be able to explain each and every evidence and form of its qiyas (al-Syak'ah, 1997; Ibn al-Salah, 1986). Thus, these two groups would use the approach of replication in making the law, by taking or directly quoting the opinions in the Shafilite school of figh in total in any particular case that was raised. 


\section{Adaptation Approach in the Deriving of Hukum}

We can see that the adaptation approach in the rule constructions in the al-Shafi'i madhhab. A basic method was applied by al-Shafili in spreading the growth of rules in his madhhab. This method allowed adaptation and changes to be made to the knowledge being transferred to align it with the context and its true meaning as well as to be in line with the Koran, alSunnah and al-ijma'. It began with the approach of al-qiyas which had been systematically introduced by al-Shafili, which forms the guide and basis to other methods that can be adapted.

In the beginning of Islam, al-qiyas was known as al-ra'y (legal understanding) which was used as a general term to reflect that it had an ijtihadiyyah element. Then al-ra'y grew to be a separate term and a concept of law, which was then known as al-qiyas which can differentiate between other forms of al-ra'y and other ijtihad (al-Asyqar, 1982). Even though there were other ulema such as Imam Abu Hanifah and Imam Malik which had mentioned al-qiyas, they didn't however identified any method that can differentiate between an incorrect opinion and a correct one as Imam al-Shafiti had done. He had outlined several items which showed the clear differences between al-qiyas and other istinbat of other rules (alGhazali 1356; al-Syak'ah, 1997).

Al-qiyas is to hold similar a problem whose verdict is not outlined within the sacred text with a problem whose verdict is mentioned in the text due to the similarities between the two problems by way of 'illah al-hukm \{a feature on which an al-asl (original) can be built whereby that feature has similarities with the feature found in al-far' (branch)\} (Abu Zahrah, 1987; Ibn Qudamah, 1495; al-Syirazi, Undated). Al-Shafi'i stressed that there are two main principles that must be complied with for it to be al-qiyas (Abu Zahrah, 1987; al-Shafi'i, 1306):

- Every problem and event that occurs to man at any time and under any circumstances can be explained by rule of syarak. This explanation is made in two forms whether via clear nas, or reasoning that has been accurately built relating to that nas. Thus, ijtihad is the right way to build evidence on the text and such ijtihad is named as al-qiyas.

- Legal knowledge is conveyed to man by way of evidence based on nas (explicit) in relation to a particular law (dilalah al-nas 'ala al-hukm) especially in respect of laws which are set out in two ways: firstly, knowledge which covers both spiritual and physical aspects which are qat'i (definite) in the text of Koran and al-Sunnah and secondly, knowledge which is, on the surface, zann (uncertain) in terms of reliability. This can be found in the hadiths ahad, al-ijma' and al-qiyas. Thus the mujtahid must use all his resources to produce an accurate and satisfactory ruling. The mujtahid would not be considered to have sinned if the ijtihad they conducted reached the wrong conclusion on the hukum.

Hence according to al-Shafi'i, al-qiyas can be said to be equal to ijtihad. This is because to carry out an ijtihad one must first use the al-qiyas channel. Al-Shafi'i accepted al-qiyas as one of the source of law in order to determine the ruling where there is no clear textual explanation on the rule in the Koran or al-Sunnah. Al-Shafii had set out several conditions which must be complied with in the application of al-qiyas, so that its implementation can only be carried out by those qualified to do so. Amongst the conditions are, fluency in Arabic language, understanding the contents of Koran in depth especially from the aspect of nasikh (the abrogating) and mansukh (the abrogated), in general and specifically, have knowledge on al-Sunnah and the opinions of the ulema al-salaf from amongst the Companions, understand the concept of khilaf (controversy, dispute, discord) which occurs in al-Sunnah and also one who is highly intellectual.

Al-Shafi'i also explained that there were several texts in the Koran and al-Sunnah on which analogies cannot be drawn, as the texts had limited use. An example is the problem of taking ablution. In the Koran, it was mentioned that to wash one's feet is one of the rules of taking ablution. According to Al-Shafi'i, when the Messenger p.b.u.h wiped both his khuf (leather socks) instead of his bare feet, this cannot be taken to be the same as replacing wetting one's forehead with the wetting of the turban. This is because the leniency was granted by law was only applicable to the khuf and not to the turban.

Additionally, al-qiyas was according to the teachings of al-Shafili purely to enable the ijtihad which must be in line with the legal justification and their objectives. To further explain this, he had stressed in his book al-Risalah: "...jitihad will never happen unless by way of searching for something, and the search for something will never happen unless guided by evidences and those evidences are al-qiyas...". According to him, any approach other than the five guiding him in the construction and research of a hukum would not be considered as an approach that can stand independently as it would tend to have wide use of al-ra'y (logic). However, on deeper analysis he had indirectly used that approach within the framework of ijtihad. This shows that he had applied a method suitable with adaptation in knowledge transfer. An example would be the use of the al-masalih al-mursalah (public interest) method. According to al-Bugha (1993), even though al-Shafi'i did not make al-masalih al-mursalah as a source of rule that can stand independently, he had solved many issues using that technique of al-masalih al-mursalah. 
Al-Haramayn had written in his book al-Burhan on al-Shafi'i's belief in the technique of al-masalih al-mursalah and he wrote about its implicit meanings. This can be understood from the words of al-Haramayn (Undated): "...and whomsoever tries to analyse the words of al-Shafi'i, will not only rely on the origin (evidences), but will also link it with the al-mursalah meanings, and if not found, will turn to similar policies". As usual he says: "two items that are pure, how does one differentiate between them". Zayd (1964) had once affirmed that al-Shafi'i did not reject the use of al-masalih . To him, the rejected al-masalih was only those which were based on desires and wants only. As long as it was not based on such, al-Shafi'i would accept it. Hadith by the Messenger p.b.u.h. which means: "whoever does an action that is not in accordance with this matter of ours will have it rejected".

Ibn Hajar al-Haythami (Undated) once interpreted the above hadith and said that al-Shafi'i had said anything that was made up and against the Koran and al-Sunnah, al-ijma' and al-athar (narration and actions of the Companions) was a wrong bid'ah (innovations), while anything that was made up, being good and is not against the Koran, al-Sunnah, alijma' and al-athar, was a commendable bid'ah. In his commentary of the above statement, al-Buti (1992) stated that what was 'something good' as mentioned by al-Shafi'i, was something that met the Shari'ah objective, as what was considered by him as bid'ah in relation to the above was its non-inclusion in the Koran and al-Sunnah. The activity would be guided by al-masalih al-mursalah. Hence this matter would be included in the adaptation approach applied in the transfer of knowledge.

Another example that can prove how al-Shafii applied the approach of al-masalih al-mursalah is relating to the retraction of testimony. To further explain, al-Shafii (1993) said:

\begin{abstract}
"If two witnesses or more testify against a man leading to his death or him receiving the punishment of amputation or caning or qisas (equal retaliation) in cases of murder or injury, punishment is then imposed based on their testimony and then they retract the testimony while saying, "We deliberately did so that the punishment is imposed on him (the victim)", then that testimony is considered to be a crime on him (the person on whom the testimony was made). In a matter that relates to qisas, the victim or the family of the victim can choose between qisas or a diyat (compensation) as punishment on them. Whereas in matters not relating to qisas, the victim can choose whether to accept a ransom or to impose the punishment of ta'zir (a sentence or punishment whose crime is not fixed by the Shari'a) on them".
\end{abstract}

His verdicts and views were not based on the Koran and al-Sunnah as the ruling on qisas was not in either of those sources that can verify the verdict on those who retract their testimony. In fact the rule was made based on alistislah or al-masalih which was in line with the ruling of qisas to control bloodshed, deceit and hatred (al-Khin, 1998). Hence, the method of al-masalih al-mursalah which had been applied indirectly by al-Shafii was seen to be compatible with the approach of adaptation in the construction of the Shafi ite rules. This situation allows adaptation and changes to be made on fields of discipline and transferred knowledge in order to align them with context and true meaning of the Koran, al-Sunnah and al-ijma:

One of the adaptation approaches in the transfer of knowledge in the construction of hukum is the technique of sadd al-dhara'i (to cover the source of damage) despite differing opinions amongst the fuqaha' (legal scholars) on this (Abdul al-Wahhab, 1991; al-Shatibi, Undated; Hasan, 1981). The difference of opinion on the view of al-Shafiit in relation to that matter was due to three factors. Firstly, it was due to the difference in views between the usul al-figh ulema then and now. Secondly, it was due to the clash between the text and the statement of al-Shafi'i relating to that and thirdly, on the surface there were some figh issues that had been solved by al-Shafi'i by relying on the sadd al-dharai' (Uthman, 1996).

To show that there were some problems of figh that had been resolved by al-Shafi'i by using the sadd al-dhara'it method in resolving a particular hukum, we are guided by his view in his book 'al-Umm' in the case of restricting flow of water in the chapter 'Ihya' al-Mawat'. He stated that whomsoever restrict flow of water, a gift from Allah the Almighty, into where grass is grown, then this action could be seen in two ways, one, to make it possible to forbid what has been allowed by Allah the Almighty and secondly, to be the basis of allowing what has been forbidden by Allah the Almighty. This shows that the al-Dhara'i' can occur in both the halal and haram situations (al-Shafi'i, 1993). In addition, al-Shafi'i had clearly not used sadd al-Dhara'i' if the matter would encourage destruction, but would not normally cause the said destruction and would not happen occasionally. An example that was often used by al-Shafiti (1993) was in aqad (contract binding) related issues. In the opinion of 'Uthman (1996), al-Shafi'i had placed emphasis specifically on the issues and declared that a way or method will not adversely affect the aqad if it meets the requirements and conditions.

From the clarification above, the technique of sadd al-dhara'i' is seen to be compatible with the adaptation approach in hukum construction within the Shafilite madhhab even though it was not accepted directly as there had been hukum determined based on the technique. This is because the method allowed for adaptation and changes to be done on the particular transferred knowledge so that it is in line with the context and true understanding and in line with Koran, 
al-Sunnah and al-ijma'. Among the adaptation method in the transfer of knowledge in the deriving of hukum is by using the technique of al-Istishab (maintaining the rule which has been previously justified until such time that new evidence proves it otherwise). Even though al-Shafi'i did not include it as one of his methods of making a law, but that did not mean that he did not apply the method in resolving any issues that arose. It can be actually proven by several of his verdicts including (al-Shafi'i 1993):

\begin{abstract}
"and when a man accuses another in the matter of slavery or others, or he accuses the committing of a crime whether intentional or not, then he makes peace with the accused, either totally or partially, based on something that was given by the accused, then if there is a settlement reached and the accused accepts the settlement, the settlement is therefore allowed based on what is allowed in a trade, whether the settlement is paid now or deferred. If the accused rejects the settlement then the settlement will be null and void and their rights revert to as before, and the accuser must refer to the claim on the accused...".
\end{abstract}

Furthermore, the majority of the Shafi'ites, including al-Muzani, al-Sayrafi, al-Suyuti and al-Ghazali accepted the usage of al-Istishab or The Law of Presumption in the context of debate (al-Amidi, Undated). Therefore, the Shafi'ite ulema had applied the adaptation approach by developing several principles or method of jurisprudence (fighiyyah) based on al-Istishab as follows (al-Suyuti, 1990):

- The original status of a thing will take precedent (al-asl baqa' ma kan 'ala ma kan). As an example, if a person is sure that he or she is in a pure state, and then he felt doubts, then the rule is that he would be in a position of purity. Conversely, if a person is confident that he is in an impure state, and he then questioned later whether he was clean or not clean, then he would be deemed to be in an impure state.

- The original status of a matter is free from responsibility (al-asl bara'ah al-dhimmah). As an example, if the accuser is unable to bring witnesses or testimony on their case and demands that the accused take an oath, and the accused remains silent, then it is not allowed to impose a sentence on the accused merely because he is silent and does not take an oath. This is because in the first place he is free from any obligations, and it is in fact the accuser that needs to take that oath.

- The original status of a matter is mubah (permissible), until such time there is proof to say that it is haram (forbidden) (al-asl fi al-ashya' al-ibahah hatta yadull 'ala al-tahrim). As an example, an animal whose state is doubtful, can it be eaten or not? In this matter there are two views of the Shafi'ites. The more accurate view is that the meat would be halal. This was the view of al-Rafili. However, according to Abu Hanifah, the original status of a thing is haram, until there appears proof to say otherwise.

This is part of the fighiyyah principles although there are other fiqhiyyah principles which were produced out of the al-Istishab. Among others, the original status of a matter is calculated to the nearest second (al-asl fi kull hadis taqdiruh bi aqrab zaman), the original status as conveyed in a conversation is the truth (al-asl fi al-kalam al-haqiqah), the original status of the matter is declared as non-existent (al-asl al-'adam) and others (al-Suyuti, 1990).

An approach of adaptation in knowledge transfer in deriving a hukum is the technique of using al-urf (tradition/society customs). Although al-Shafiti did not list tradition (urf) as one of the methods to determine a ruling, alShafi'i's qawl qadim (older opinions) and qawl jadid (new opinions) seem to suggest that his method was influenced by al'urf in resolving a particular issue of figh. This is caused by environmental differences, and differences in customs and circumstances. In other words, he changed his fatwa in Iraq, after he moved to Egypt, influenced by the local 'urf. He had found the environment and 'urf in Egypt to be different from that in Baghdad. Based on the local values in Egypt, he had reassessed his qawl qadim (older views) which was based on the reality in Baghdad and Hejaz to qawl jadid (new views) based on reality in Egypt (Abu Zahrah, 1987; Madkur, 1969; Abd al-Salam, 1988; Ali, 2000).

To prove that al-Shafi'i had applied current and 'urf (local values) indirectly in providing explanation, Imam Nawawi had written on the views of Abu 'Ubaydah, who reviewed al-Shafil's view on athar (narration) by Sayyidina 'Umar alKhattab who had said (Ali, 2000): "a person shall not be allowed to consume the oil sold in the form of al-awaqi". In elaborating the meaning, al-awaqi, al-Shafi'i had made it equal to a form of measurement i.e. kaylan based on the 'urf used at that time whereas the dalil (justification) used showed that originally the sale and purchase of oil used the method of waznan (weighing). In addition, his view was different from the present 'urf, which is in the form of waznan (weighing) (al-Nawawi, 1997). In the meantime, Shafi'ite ulema had made 'urf or custom as one of the general fighiyyah principle or method, that is, 'al-'Adah Muhakkamah' (acknowledged custom) (al-Suyuti, 1990). The technique of al-'urf (custom) therefore in the transfer of knowledge is known as an adaptation approach in deriving hukum among the Shafi'ites. Even though it had not been directly accepted there were several rulings made based on that technique. This is because alShafi'i himself allowed adaptation and change to be made on knowledge which was being transferred, caused by 
changes due to environment, custom and circumstances. This can be seen to be in line with the context and true meaning as contained in the Koran, al-Sunnah and al-ijma:

There were those within the Shafi'i madhhab ulema who were able to conduct ijtihad and produce their views as well as adapt the knowledge which was transferred to them from Imam al-Shafili. They were made of two groups as follows (al-Nawawi, 1997; Ibn al-Salah, 1986):

- Mujtahid muntasib: He is an 'alim who had not practised taqlid in his imam's madhhab and his daleel as he would be able to master the disciplines of knowledge that should be mastered by a mujtahid mutlaq. However, he is also known as a mujtahid within a madhhab as his ijtihad would be bound by and would be guided by his Imam's methodology in disseminating his views.

- Mujtahid: An 'alim who is able to conduct ijtihad within the boundaries of his Imam's schools of jurisprudence. In other words, he would still be bound by the matters of takhrij with the policies taught by his Imam. Hence he would be able to explain the teachings of his madhhab based on the daleel and methods practised by his Imam. However, he would not meet all the criteria of a mujtahid mutlaq due to deficiencies in knowledge and tools required to be a mujtahid mutlaq. This group is named Ashab al-Wujuh wa al-Turuq fi al-Madhhab.

In the efforts to assist the spread of the teachings of the Shafi ites, the majority of mujtahidin ulema in the madhhab would still be bound by the ruling methodologies taught by al-Shafi'i and only a few had gone against them. However, for each view issued, it is deemed as a view of the Shafi ites if the said view is not against the policies he had set and does not contradict his views. This does not occur in the Hanafi madhhab as most of the views of students under Imam Abu Hanifah were against his (Amin, 1964; al-Haqq, 1991).

In relation thereto, there were amongst them those who were able to extract the rule from hadith via takhrij and istinbat on the rule. From the aspect of reliance of their takhrij on the Shafi'ites, this can be categorised into two parts (Abu Zahrah, 1987):

- Opinions that are considered as outside the Shafiites: This occurs when a view that had been takhrij by the mujtahid contradicts the findings of al-Shafii on his rule in any particular case. In the meantime, the mujtahid's views would also be considered to be out of the madhhab if they breached the methodologies or fundamentals set by al-Shafi'i. These acts were committed by only a few of his students relating to a few issues, which had been individually assessed via takhrij.

- Views that can be categorised as from the Shafi'ites even though there was no clear finding from al-Shafiit. This is the view that had been extracted from fundamentals introduced by him and the views were not against the Imam's views. However, the mujtahidin ulema in the madhhab did not consider those types of views as the views of al-Shafiti but as 'wajhan min wujuh al-madhhab'. This is because al-Shafi'i did not actually have that view but it was extracted based on his policies or using his methodologies. Nevertheless, the views are included in the Shafi'i madhhab.

In addition, there were other matters which had been extracted which were disputed by the ulema, whether they were included in the views of Shafi' ites or otherwise (al-Nawawi, 1997; Abu Zahrah, 1987):

- The matters that had been discussed and agreed by the mujtahidin ulema within the Shafi ites which did not contradict the views of al-Shafii but were not bound by the techniques and methodologies introduced by him, named as wajh within the madhhab. However, if the mujtahidin ulema held an opinion independently and it was not known whether their opinion was made based on the teachings of al-Shafiti or otherwise, but he was nonetheless well known amongst the mujtahidin ulema who strongly believe in the fundamentals and methods of al-Shafi'i such as al-Ghazali, al-Qaffal and such like, the views would be considered the views of the madhhab.

- The mujtahidin ulema chose the opinions that had been retracted by al-Shafi'i. The majority of the ulema shared the view that those cannot be a Shafi'ite opinion.

- The mujtahidin ulema found a valid hadith that is against the opinion of al-Shafi'i, and they uphold the hadith in preference of the view of him. In this matter, there was conflict as to whether such opinion is included in the Shafiti madhhab or otherwise. The majority of them felt that it should be, and others were more hesitant.

Thus, it can be seen that there existedamong the ulema of Shafii madhhab themselves those who applied the adaptation technique in the derivation of rules by using their mental strength to find the solution of any particular case brought to their attention. 


\section{Conclusion}

Therefore, from the analysis in this paper, it is obvious that the approach of knowledge transfer had been applied by previous scholars from the early ages, that is, from the glorious Islamic era. This is proven by the method of replication found in the transfer of knowledge which had been adopted by the Shafi'ite scholars through the Koran, Al-Sunnah and al-ijma' based approach. The method of adaptation in transferring knowledge was also seen to have been used in applications based on al-Qiyas, al-masalih al-mursalah, sadd al-dhara'i' and al-istishab to name a few. It is therefore clear that the approach of transferring knowledge that has only been extensively analysed and studied under the field of management science this 21st century had long been used in Islam, especially among the scholars of Islam themselves, and in particular here, by the Shafi'ite school of jurisprudence.

\section{Acknowledgement}

This study is financed by the Research Group of Arabic Culture and Islamic Civilization (KUKAPI, DPP-2014-068), UKM; and the Action/Strategic Research Group (PTS-2014-068), UKM.

\section{References}

'Abd al-Salam, Ahmad Nahrawi. (1988). al-Imam al-Shafi' fi madhhabih al-qadim wa al-jadid. Cairo: Dar al-Fikr al-'Arabi. 'Abd al-Wahhab, Ibn al-Subki Taj al-Din. (1991). al-Ashbah wa al-naza'ir. Beirut: Dar al-Kutub al-'Ilmiyyah. Abu Talib, Sufi Hasan. (1990). Tatbiq al-shari'ah al-Islamiyyah fi al-bilad al-'Arabiyyah. Vol. 3. Cairo: Dar al-Nahdah al-'Arabiyyah. Abu Yusuf, Ya'qub ibn Ibrahim. (1352). al-Kharaj. Cairo: al-Matba'ah al-Salafiyyah. Abu Zahrah, Muhammad. (1948). Abu Hanifah hayatuh wa 'asruhu. Cairo: Dar al-Fikr. Abu Zahrah, Muhammad. (1987). Imam al-Shafi'i. Cairo: Dar al-Fikr al-'Arabi. Abu Zahrah, Muhammad. (1987). Tarikh al-madhahib. Cairo: Dar al-Fikr al-'Arabi. al-'Asqalani, Ibn Hajar. (1301). Tawali al-ta'sis. Cairo: Matba'at al-Muniriyyah. al-Amidi, 'Ali b. Abu 'Ali. (1347). al-Ihkam fi usul al-ahkam. Beirut: Dar al-Kitab al-'Arabi. al-Asyqar, 'Umar Sulayman. (1982). Tarikh al-figh al-Islami. Kuwait: Maktabat al-Falah. Ali, Abdul Karim \& Ismail, Muhamad Safiri. (2007). Tajdid figh madhhab Syafii di Malaysia. Jurnal Fiqh, 4, 27-32.

Ali, Abdul Karim. (2000). In Paizah Ismail and Ridzwan Ahmad (Eds.), Fiqh Malaysia ke arah pembinaan fiqh tempatan yang terkini. Kuala Lumpur: Academy of Islamic Studies, Universiti of Malaya.

Amin, Ahmad. (1964). Duha al-Islam. $7^{\text {th }}$ ed. Cairo: Matba'at Lajnah al-Ta'lif wa al-Tarjamah wa al-Nashr. al-Baghdadi, Abu Bakr Ahmad ibn 'Ali al-Khatib. (1997). Tarikh Baghdad. Mustafa 'Abd al-Qadir (ed.). Beirut: Dar al-Kutub al-'Ilmiyyah. al-Bannani, 'Abd al-Rahman. (Undated). Hashiyat al-bannani 'ala sharh al-mahalli 'ala jam' al-jawami'. Cairo: al-Matba'ah al-Amirah. Bik, Muhammad al-Khudari. (1965). Tarikh al-tashri' al-Islami. Cairo: al-Maktabah al-Tijariyyah al-Kubra. al-Bugha, Mustafa Dayb. (1993). Athar al-adillah al-mukhtalaf fiha fi al-figh al-Islami. Vol. 2. Damascus: Dar al-Qalam. al-Buti, Muhammad Said Ramadan. (1992). Dawabit al-maslahah fi al-shari'ah al-Islamiyyah. Beirut: Mu'assasat al-Risalah. al-Ghazali, Abu Hamid. (1356). al-Mustasfa min 'ilm al-usul. Cairo: Matba'ah al-Mutanabbi. Hasan, Husayn Hamid. (1981). Nazariyyat al-maslahah fi al-figh al-Islami. Cairo: Matba'ah al-Mutanabbi. al-Haqq, Jad al-Haqq 'Ali Jad. (1991). al-Figh al-Islami nash'atuh wa tatawwaruh. Cairo: Dar al-Syabab. al-Haramayn, 'Abd al-Malik ibn 'Abd Allah al-Juwayni. (Undated). al-Burhan fi usul al-figh. Cairo: Dar al-Kutub. Hasyim, Ahmad 'Umar. (1995). Qawa'id usul al-hadith. Cairo: Dar al-Shabab.

Hollins, E.R., King, J.E., \& Hayman, W.C. (Eds.). (1994). Teaching diverse populations: Formulating a knowledge base. Albany: State University of New York Press.

Ibn al-Qayyim, Muhammad ibn Abu Bakr. (Undated). I'lam al-muwaqqi'in 'an rabb al-'alamin. Beirut: Dar al-Jayl. Ibn al-Salah. (1986). Fatawa wa masa'il Ibn al-Salah. Beirut: Dar al-Ma'rifah. Ibn Hajar al-Haytami, Abu al-'Abbas Ahmad Shihab al-Din ibn Muhammad. (Undated). Tuhfat al-muhtaj fi sharh al-minhaj. In al-Shirwani, 'Abd al-Hamid \& al-'Ibadi, Ahmad ibn Qasim. Hawashi tuhfat al-muhtaj bi sharh al-minhaj. Cairo: Matba'at Mustafa Muhammad. Ibn Qudamah, 'Abd Allah ibn Ahmad. 1405. al-Mughni. Beirut: Dar al-Fikr. Khallaf, 'Abd al-Wahhab. (Undated). 'IIm usul al-hadith. Cairo: Maktabat al-Da'wah al-Islamiyyah li Shabab al-Azhar. al-Khin, Mustafa Sa'id. (1998). Athar al-ikhtilaf fi al-qawa'id al-usuliyyah fi ikhtilaf al-fuqaha'. Beirut: Mu'assasat al-Risalah. Madkur, Muhammad Salam. (1969). al-Madkhal li al-figh al-Islami. Cairo: Dar al-Nahdhah al-'Arabiyyah. al-Nawawi, Muhy al-Din Abu Zakariyya ibn Sharf. (1997). al-Majmu' sharh al-muhadhdhab. 20 Vol. (v. 1-9 by al-Nawawi, v. 10-12 by alSubki, 'Ali ibn 'Abd al-Kafi and v. 13-20 by al-Muti'i, Muhammad Najib). Medina: al-Maktabah al-Salafiyyah. Pai, Y. (1990). Cultural foundations of education. New York: Merrill Macmillan. al-Qal'aji, Muhammad Rawwas \& al-Qunaybi, Hamid Sadiq. (1985). Mu'jam lughah al-fuqaha'. Beirut: Dar al-Nafa'is. al-Qaradawi, Yusuf. (1990). Madkhal li dirasah al-syari'ah al-Islamiyyah. Cairo: Maktabah Wahbah. al-Razi, Abu 'Abd Allah Muhammad. (Undated). Manaqib al-imam al-Shafi'i. Cairo: Maktabat al-'Allamah. 
al-Shafi'i, Abu 'Abd Allah Muhammad ibn Idris. (1309). al-Risalah. Shakir, Ahmad Muhammad (Ed.). Beirut: al-Maktabah al-'Ilmiyyah. al-Shafi'i, Abu 'Abd Allah Muhammad ibn Idris. (1993). al-Umm. Beirut: Dar al-Ma'rifah.

al-Sheikh Abdul Halim bin Abdul Kadir. (2008). Shafi'ite hukum. Interview, May 2.

Smith, G.P. (1998). Common sense about common knowledge: The knowledge bases for diversity. Washington D.C.: American Association of Colleges for Teacher Education.

al-Suyuti, Jalal al-Din ibn 'Abd al-Rahman. (1990). Ashbah wa al-naza'ir. Beirut: Dar al-Kutub al-'Ilmiyyah.

al-Shak'ah, Mustafa. (1997). Islam bi la madhhab. Cairo: Dar al-Misriyyah al-Lubnaniyyah.

al-Shatibi, Ibrahim ibn Musa. (Undated). al-Muwafaqat fi usul al-syari'ah. Muhammad 'Abd Allah Darraz \& 'Abd al-Salam Shafi Muhammad (ed.). Vol. 4. Beirut: Dar al-Kutub al-'Ilmiyyah.

al-Shirazi, Ibrahim ibn Ali. (Undated). al-Muhadhdhab. Beirut: Dar al-Fikr.

Szulanski, G. (2000). The process of knowledge transfer: A diachronic analysis of stickiness. Organisational Behaviour and Human Decision Processes, 82(1), 9-27.

Szulanski, G., Winter, S.G., Cappetta, R., Vanden, C. (2002). Opening the black box of knowledge transfer: The role of replication accuracy. Wharton.

'Uthman, Mahmud Hamid. (1996). Qa'idat sadd al-dhara'i' wa atharuha fi al-figh al-Islami. Cairo: Dar al-Hadith.

Williams, C. (2007). Transfer in context: Replication and adaptation in knowledge transfer relationships. Strategic Management Journal, 28, 867-889.

Zayd, Mustafa. (1964). al-Maslahah fi tashri' al-Islami. Cairo: Dar al-Fikr al-'Arabi.

al-Zuhayli, Wahbah. (1988). Usul al-figh al-Islami. Damascus: Dar al-Fikr. 